\title{
Review \\ Cognitive Impairment in Anti-Phospholipid Syndrome and Anti-Phospholipid Antibody Carriers
}

\author{
Fadi Hassan ${ }^{1,2,+}$, Mohammad E. Naffaa ${ }^{1,2, *,+}\left(\mathbb{D}\right.$, Amir Saab $^{2,3}$ and Chaim Putterman ${ }^{2,4,5}$ \\ 1 Rheumatology Unit, Galilee Medical Center, Naharyia 2210001, Israel; fadihh@gmail.com \\ 2 Azrieli Faculty of Medicine, Bar-Ilan University, Safed 1311502, Israel; amirs@gmc.gov.il (A.S.); \\ chaim.putterman@einsteinmed.edu (C.P.) \\ 3 Internal Medicine "E", Galilee Medical Center, Naharyia 2210001, Israel \\ 4 Division of Rheumatology, Albert Einstein College of Medicine, Bronx, NY 10461, USA \\ 5 Research Institute, Galilee Medical Center, Naharyia 2210001, Israel \\ * Correspondence: mohammadn@gmc.gov.il; Tel.: +972-49107038 \\ + These authors contributed equally to this work.
}

Citation: Hassan, F.; Naffaa, M.E.; Saab, A.; Putterman, C. Cognitive Impairment in Anti-Phospholipid Syndrome and Anti-Phospholipid Antibody Carriers. Brain Sci. 2022, 12, 222. https://doi.org/10.3390/ brainsci12020222

Academic Editors: Boel De Paepe and Carla Masala

Received: 27 November 2021

Accepted: 2 February 2022

Published: 5 February 2022

Publisher's Note: MDPI stays neutral with regard to jurisdictional claims in published maps and institutional affiliations.

Copyright: () 2022 by the authors. Licensee MDPI, Basel, Switzerland This article is an open access article distributed under the terms and conditions of the Creative Commons Attribution (CC BY) license (https:// creativecommons.org/licenses/by/ $4.0 /)$.

\begin{abstract}
Cognitive impairment is frequently reported among anti-phospholipid syndrome (APS) patients as well as anti-phospholipid antibody (aPL) carriers, but it is less studied than other manifestations of this condition. Moreover, the exact prevalence of cognitive impairment in these patients has not been accurately determined, mainly due to inconsistency in the tools used to identify impairment, small sample sizes, and variability in the anti-phospholipid antibodies measured and positivity cutoffs. The notion of a direct pathogenic effect is supported by the observation that the higher the number of aPLs present and the higher the load of the specific antibody, the greater the risk of cognitive impairment. There is some evidence to suggest that besides the thrombotic process, inflammation-related pathways play a role in the pathogenesis of cognitive impairment in APS. The cornerstone treatments of APS are anti-coagulant and anti-thrombotic medications. These treatments have shown some favorable effects in reversing cognitive impairment, but solid evidence for the efficacy and safety of these treatments in the context of cognitive impairment is still lacking. In this article, we review the current knowledge regarding the epidemiology, pathophysiology, clinical associations, and treatment of cognitive impairment associated with APS and aPL positivity.
\end{abstract}

Keywords: cognitive impairment; dementia; anti-phospholipid syndrome; anti-phospholipid carrier

\section{Introduction}

Anti-phospholipid syndrome (APS) is an acquired systemic disorder associated with the presence of anti-phospholipid antibodies (aPLs). The classic aPLs include anti-cardiolipin antibodies $(\mathrm{aCL})$, lupus anticoagulant (LA), and the more recently described anti- $\beta 2$ glycoprotein I antibodies (a $\beta 2$ GPI) [1]. The primary clinical manifestations of APS are arterial and venous thrombosis, or both, as well as pregnancy morbidity [1]. The presence of at least one aPL antibody without a prior thrombosis or obstetric morbidity determines the presence of an aPL carrier [2]. By contrast, the presence of at least one aPL antibody on two separate occasions, at least 12 weeks apart, accompanied by a history of either a thrombotic event or pregnancy morbidity, is required for the diagnosis of APS [1,3]. APS may occur independently (known as primary APS) or secondary to other autoimmune diseases (known as secondary APS), mainly in the form of systemic lupus erythematosus (SLE) [3].

Neurologic involvement in APS is prevalent and responsible for significant morbidity and mortality [3]. APS may affect the nervous system through several patterns, primarily stroke and transient ischemic attacks (TIA). Besides these more common manifestations, 
neurologic involvement in APS may manifest as venous sinus thrombosis, cognitive impairment and dementia, psychosis, seizures, movement disorders, headaches, demyelinating syndromes, transverse myelitis, and ischemic optic neuropathy [4].

To date, most studies examining cognitive impairment in aPL carriers and in APS have included a small sample size and varied considerably in terms of cognitive impairment detection methods, the particular aspects of cognition evaluated, and the specific antibody type (aCL, LA or aß2GPI) and the laboratory cutoffs used to define positivity [5]. This complexity in the interpretation of the results is further increased by the following (Table 1): firstly, aPL can be found in the general population with a prevalence of 1-5\% [5]. Most of these cases, however, especially if the aPLs are detected at low titers, do not progress to a thrombotic event or cognitive decline, and patients may remain asymptomatic. Thus, aPL carriers represent a highly heterogeneous group of patients, who vary considerably in terms of prognosis and cognitive impairment risk. Secondly, the lack of standardized methods for aPL quantification, which also changes over time, and modifications in the cut-off levels for positivity, lead to further difficulty in comparing the results of different studies. Third, APS can be secondary to autoimmune disease, which may itself affect the central nervous system and cause cognitive impairment. Fourth, aPL antibodies are found in increased frequency in the elderly, among whom cognitive impairment and dementia are common [6]. Thus, the exact frequency and mechanisms of cognitive impairment in APS and their association with aPL activity, as well as the proper approach to diagnosis and treatment, remain unclear [4].

Table 1. Factors limiting the comparability across studies of cognitive impairment in aPL carriers.

- $\quad$ aPL can be found in the general population, but most cases are not associated with cognitive decline.

- $\quad$ aPL quantification is performed using various methods.

- Cut-off levels for positivity for aPL have changed over time.

- $\quad$ APS can be secondary to autoimmune disease, which may itself affect cognition.

- The prevalence of aPL antibodies increases in the elderly population, in which cognitive impairment and dementia are also common.

aPL-anti-phospholipid antibodies; APS—anti-phospholipid syndrome (APS).

In this review, we summarize the available data regarding the possible associations between cognitive decline associated with aPL and APS. We discuss the epidemiology, pathophysiology, clinical manifestations, and recommendations for management, with an emphasis on the European League Against Rheumatism (EULAR)'s recommendations for the treatment of APS.

\section{Epidemiology}

\subsection{Definitions}

Dementia is characterized by a decline in cognition from the previous level of function that interferes with daily function and independence. It usually involves one or more cognitive domains (social cognition, complex attention, learning and memory, executive function, language, perceptual-motor). Cognitive impairment is a clinical state between normal cognition and dementia [7]. Several tests have been used for assessing cognitive impairment and dementia, but the Mini-Mental State Examination (MMSE) and the Montreal Cognitive Assessment (MoCA) are most commonly used, with a sensitivity of 75-92\% and a specificity of $81-91 \%$, respectively [8].

\subsection{Carriers of $a P L$}

Cognitive impairment is reported in aPL-positive individuals with a frequency that ranges between 19\% to 40\% [9-11]. A systematic literature review by Bucci et al. reported a prevalence ranging between $5.9 \%$ and $31.1 \%$ [12]. Among aPL-positive elderly people (>65 years old), an association between high aCL titers (mainly IgG subtype) and cognitive impairment has been reported [13]. In aPL-positive, non-elderly, asymptomatic adults, 
an increased frequency of cognitive impairment was also documented compared to age and education-matched controls (33\% vs. 4\%) [9]. An association between aPLs and brain infarction, as well as cognitive and motor decline, was also reported [14]. Among aPL carriers, cognitive dysfunction is much more common than dementia (19-40\% vs. $0-6 \%$, respectively), although the latter condition has been reported as well. Supporting the possible role of aPLs as pathogenic factors that can contribute to cognitive decline, two studies demonstrate that aPLs are significantly more prevalent among patients with dementia than in individuals with preserved cognition $[15,16]$.

\subsection{APS Patients}

A correlation between cognitive impairment and high levels of aPL was similarly reported in primary and secondary APS [17-19]. However, other studies did not find a significant association between the presence of aPLs and cognitive impairment [20,21]. It is worth noting that all three types of aPL antibody are associated with a risk of cognitive impairment, with the exception of IgM aß2GPI, which does not confer the same risk. Moreover, the risk of cognitive impairment increases with the number of antibody types detected, and the higher the titer and the persistence over time of the specific aPL, the greater the risk of cognitive impairment [22].

Among primary APS patients, the frequency of cognitive impairment ranges between 42 and $80 \%$, compared to the $7-75 \%$ range observed in patients with secondary APS [17,23-29]. The frequency of dementia and its association with APS have not been rigorously studied in APS patients [5]. The frequency of dementia in primary APS varies widely, ranging from 1.9-2.5\% (elderly and non-elderly patients) to 56\% (cohort including only elderly APS patients) [30-32]. In secondary APS (aPL-positive SLE patients), the frequency of dementia ranges from $21-54 \%$ compared to $4-7 \%$ in aPL-negative SLE patients, emphasizing once again the possible contributions of aPL to dementia [16-19,28,29,33-35].

Two recent systematic literature reviews reported that the prevalence of cognitive impairment among aPL carriers, primary APS, and secondary APS, when considered together as a group, ranges between 15 and $42 \%$ [36,37].

In a very recent study by Sevim et al., the APS ACTION registry, which aimed to describe the baseline characteristics of about 800 patients with aPL positivity, cognitive impairment was reported in $85(11 \%)$ patients [38]. In the group of patients with aPL positivity without APS, $11(7 \%)$ patients had cognitive impairment, while the group of patients with aPL positivity and APS 74 (12\%) had cognitive impairment. Furthermore, the prevalence of cognitive impairment among APS patients was higher in patients with thrombotic APS than in patients with obstetric APS, $53(12 \%)$ vs. $3(4 \%)$, respectively. When examining the prevalence of cognitive impairment according to the antibody type and number of positive aPLs, patients with double and triple positivity had higher prevalence than patients with single positivity, $20(12 \%)$ and $33(12 \%)$ vs. 17 (8\%), respectively. Moreover, patients with single LAC positivity had a slightly higher prevalence of cognitive impairment compared to patients with non-LAC single positivity, $14(8 \%)$ vs. $3(6 \%)$, respectively.

\section{Pathophysiology}

The pathogenesis of cognitive impairment in APS has not been fully elucidated. Historically, cognitive impairment in APS was mainly attributed to aPL antibody-related microvascular thrombosis resulting from hypercoagulability, with venous and/or arterial thrombosis. The pro-thrombotic effects of aPL through endothelial dysfunction, the activation of platelets, complement, and the coagulation cascade, are well known [3,5]. Antovic et al. proposed that the impairment of the fibrinolysis process may further drive the prothrombotic mechanism in APS [39]. However, more recent studies demonstrated that aPL patients with cognitive decline may have normal brain images on magnetic resonance imaging (MRI), with no evidence of thrombotic events [13]. Thus, cognitive impairment in aPL patients cannot be simply explained by ischemic events. 
To explain the possible non-thrombotic contribution of aPL to brain injury, investigators assessed animal models. In a murine model of APS, mice developed neurological and behavioral disorders, including hyperactivity, memory impairment, and aggression, without any evidence of thrombosis [40,41]. Furthermore, the intracerebroventricular injection of aPL antibodies from APS patients directly into mouse brains caused impairment in cognitive performance and the onset of hyperactive behavior [42]. The microscopic examination of brain tissue in mouse models of APS with cognitive impairment revealed a mononuclear inflammatory infiltrate in the choroid plexus and the hippocampus without evidence of ischemic lesions [41,43-45]. In vitro studies also showed that aPL antibodies bind to central nervous system neuronal cells [42]. In some studies, the degree of cognitive impairment correlated with aPL titers [41]. The direct binding of aPL antibodies to brain tissue, the relationship between the titer of aPL and the degree of cognitive impairment, and the mononuclear inflammatory infiltrate in brain tissue, all suggest a direct effect of aPL antibodies on brain tissue through an inflammatory mechanism, the nature of which remains to be determined. Moreover, several case reports showed that dementia and other neurologic features of APS may be reversible through the initiation of immunosuppression, emphasizing the possibility of inflammatory pathways acting as driving mechanisms for cognitive impairment [46].

These findings suggest that autoimmune mechanisms may underlie, at least partially, the cognitive impairment observed in patients with aPLs. Thus, cognitive impairment in these patients may actually be a result of the combined effects of hypercoagulability, blood-brain barrier disruption, the activation of pro-inflammatory mechanisms as a result of the direct binding of aPL to brain tissue, and genetic predisposition (Figure 1).

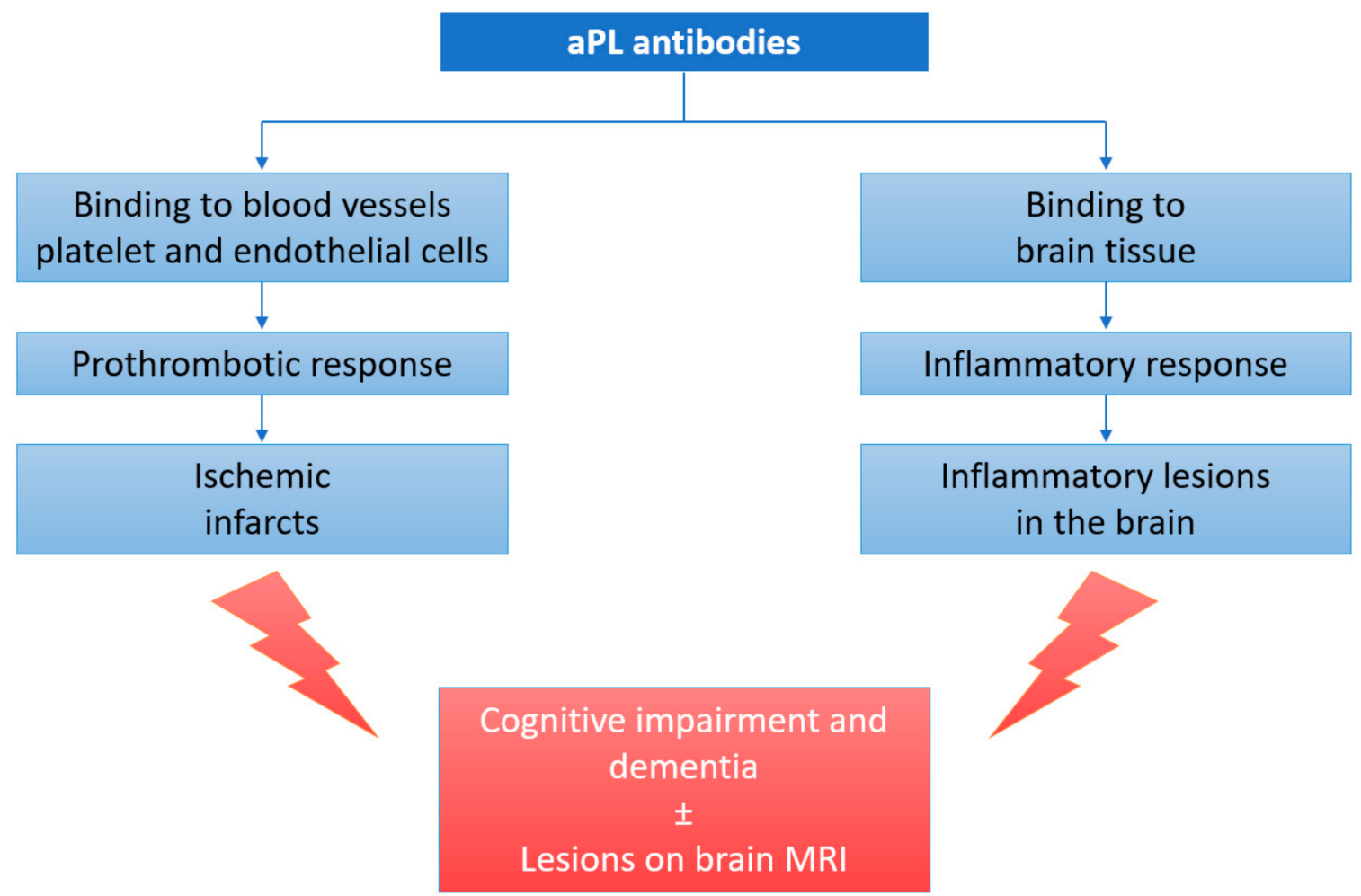

Figure 1. Pathophysiology of cognitive impairment in aPL carriers and APS patients. aPL-antiphospholipid antibodies; MRI-magnetic resonance imaging.

A recent study by Rosa et al. examined the association between brain-derived neurotrophic factor (BDNF), a neuroprotective mediator, and cognitive impairment in primary APS, with lower levels of BDNF associated with cognitive impairment in these patients [47]. 


\section{Clinical Manifestations}

Cognitive function is a composite of various domains, including perception, motor skills and construction, attention and concentration, memory (including working, declarative, procedural, semantic, and prospective), executive functioning, processing speed, and language/verbal skills. A variety of tools and questionnaires have been developed to assess different aspects of cognition. Each test was developed and tested in different groups of patients and thus has a specific reliability, validity, sensitivity, specificity, and positive predictive value, which together determine the usefulness of each test and the clinical scenario for which it is best suited [48]. Incorporating large batteries of tests (e.g., Wechsler tests) typically provides better cognitive evaluation and good validity.

Table 2 provides a summary of studies evaluating cognitive impairment in aPL carriers and APS patients. It is important to note that these studies employed multiple methods and tests to assess cognitive performance. For instance, Schmidt et al. performed a study on a German-speaking population using validated German language-based tools, while other researchers chose different tests to assess cognition. This variability is understandable but significantly limits comparability across studies.

Table 2. Cognitive impairment in aPL carriers and APS patients.

\begin{tabular}{|c|c|c|c|c|c|}
\hline Study & $\begin{array}{c}\text { Study } \\
\text { Population }\end{array}$ & Control Group & Cognitive Tests & Main Results & $\begin{array}{l}\text { Cognitive } \\
\text { Impairment } \\
\text { Frequency }\end{array}$ \\
\hline \multicolumn{6}{|c|}{ aPL Carriers } \\
\hline $\begin{array}{l}\text { Schmidt et al., } \\
1995 \text { [13] }\end{array}$ & $\begin{array}{l}\text { Elderly } \\
\text { subjects } \\
(n=53)\end{array}$ & $\begin{array}{l}\text { Age-matched } \\
\text { non- aPL carriers }\end{array}$ & $\begin{array}{l}\text { MWT-B, Janke and Debus, LGT-3, } \\
\text { WCST, Alters Konzentrations of Gatterer, } \\
\text { Purdue Pegboard }\end{array}$ & $\begin{array}{c}\text { Impaired memory and } \\
\text { visuopractical abilities. } \\
\text { No brain abnormalities or differences in } \\
\text { brain MRI. }\end{array}$ & Not reported \\
\hline $\begin{array}{l}\text { Jacobson et al., } \\
1999 \text { [9] }\end{array}$ & $\begin{array}{l}\text { Asymptomatic, } \\
\text { aPL-carriers, } \\
\text { non-elderly } \\
\text { adults }(n=27)\end{array}$ & $\begin{array}{l}\text { Age- and } \\
\text { education- } \\
\text { matched } \\
\text { non-aPL carriers }\end{array}$ & $\begin{array}{l}\text { Wechsler, CVLT, Benton line orientation, } \\
\text { COWAT, finger oscillation, grooved } \\
\text { pegboard, RCFT, trail making, WCST, } \\
\text { Beck, state-trait anxiety inventory }\end{array}$ & $\begin{array}{l}\text { Impaired executive functioning, verbal } \\
\text { learning, memory, and } \\
\text { visuospatial abilities. } \\
\text { Attentional processes and fine motor skills } \\
\text { appeared unaffected. }\end{array}$ & $\begin{array}{l}33 \% \text { in aPL } \\
\text { carries vs. } 4 \% \\
\text { in controls }\end{array}$ \\
\hline $\begin{array}{l}\text { Erkan et al., } \\
2010[10]\end{array}$ & $\begin{array}{l}\text { High titers of } \\
\text { aPL antibodies } \\
\quad(n=85)\end{array}$ & $\begin{array}{l}\text { Moderate titers } \\
\text { of aPL antibodies } \\
(n=58)\end{array}$ & Not specified & $\begin{array}{l}\text { Increased prevalence of cognitive } \\
\text { impairment in the higher-titer group in a } \\
\text { linear pattern }\end{array}$ & $\begin{array}{l}12 \% \text { in high } \\
\text { titers vs. } \\
3 \% \text { in } \\
\text { moderate } \\
\text { titers group }\end{array}$ \\
\hline $\begin{array}{l}\text { Kozora et al., } \\
2014 \text { [11] }\end{array}$ & $\begin{array}{l}\text { Non SLE } \\
\text { aPL-carriers } \\
(n=20)\end{array}$ & $\begin{array}{c}\text { SLE patients } \\
\text { with negative aPL }\end{array}$ & $\begin{array}{l}\text { FSIQ, Wechsler digit symbol and block } \\
\text { design, trail making, Stroop color and } \\
\text { word, CVLT, Rey-O Immediate, Rey-O } \\
\text { Recall, LNST, COWAT, PASAT, Dig Vig, } \\
\text { category test, finger tapping test }\end{array}$ & $\begin{array}{c}\text { High frequency of cognitive impairment in } \\
\text { both groups with no significant difference } \\
\text { between the groups }\end{array}$ & $\begin{array}{c}40 \% \text { in } \\
\text { non-SLE aPL } \\
\text { carriers vs. } \\
60 \% \text { in the SLE } \\
\text { non aPL } \\
\text { carriers }\end{array}$ \\
\hline \multicolumn{6}{|c|}{ Primary APS } \\
\hline $\begin{array}{l}\text { Tektonidou } \\
\text { et al., } 2006 \text { [24] }\end{array}$ & $\begin{array}{l}\text { Primary APS } \\
(n=39) \text { and } \\
\text { secondary } \\
\text { APS (SLE } \\
\text { related) } \\
(n=21)\end{array}$ & $\begin{array}{l}\text { Healthy age-, } \\
\text { sex-, and } \\
\text { education- } \\
\text { matched } \\
\text { controls }\end{array}$ & $\begin{array}{c}\text { Wechsler digit span, symbol and block } \\
\text { design, Rey AVLT, RCFT, SCWT, } \\
\text { TMT, COWAT. }\end{array}$ & $\begin{array}{l}\text { Impairment of visual learning, memory, } \\
\text { visuomotor and visuospatial speed and } \\
\text { flexibility, verbal fluency, and rapid } \\
\text { auditory information processing impaired. } \\
\text { No difference between primary APS and } \\
\text { secondary APS } \\
\text { Predictors for cognitive impairment: } \\
\text { Livedo reticularis and presence of white } \\
\text { ma ter lesions on MRI }\end{array}$ & $\begin{array}{l}42 \% \text { in APS } \\
\text { patients vs. } \\
18 \% \text { in the } \\
\text { controls }\end{array}$ \\
\hline $\begin{array}{l}\text { Coin et al., } \\
2015 \text { [23] }\end{array}$ & $\begin{array}{c}\text { Primary APS } \\
(n=15), \\
\text { Secondary } \\
\text { APS with SLE } \\
(n=12) \text { and } \\
\text { SLE without } \\
\text { aPLs }(n=27)\end{array}$ & $\begin{array}{l}\text { Healthy, age- } \\
\text { and education- } \\
\text { matched } \\
\text { controls }\end{array}$ & $\begin{array}{l}\text { TAVEC, RCFT, Stroop color and word } \\
\text { test, verbal phonemic fluency and } \\
\text { semantic fluency (Spanish version), Ruff } \\
\text { 2\&7 selective attention test. }\end{array}$ & $\begin{array}{l}\text { Impaired executive functions and memory } \\
\text { (verbal and visual) }\end{array}$ & $\begin{array}{c}80 \% \text { in } \\
\text { primary APS, } \\
75 \% \text { in } \\
\text { secondary } \\
\text { APS with SLE, } \\
48 \% \text { in SLE } \\
\text { without aPLs, } \\
\text { and } 16 \% \text { in the } \\
\text { controls }\end{array}$ \\
\hline \multicolumn{6}{|c|}{ Secondary APS } \\
\hline $\begin{array}{l}\text { Maeshima } \\
\text { et al., } 1992 \text { [25] }\end{array}$ & $\begin{array}{l}\text { Secondary } \\
\text { APS with SLE } \\
\quad(n=21)\end{array}$ & Healthy controls & $\begin{array}{l}\text { MMSE, “Kana" pick-up test, Miyake's } \\
\text { paired associated memory scale, word } \\
\text { recall, digit span, Watamori method, line } \\
\text { bisection test, line cancellation task, } \\
\text { recognition of intricate pictures and } \\
\text { perspective cube copying test. }\end{array}$ & Higher cortical impairment in study group & $\begin{array}{l}76 \% \text { vs. } \\
\text { missing data }\end{array}$ \\
\hline
\end{tabular}


Table 2. Cont.

\begin{tabular}{|c|c|c|c|c|c|}
\hline Study & $\begin{array}{c}\text { Study } \\
\text { Population }\end{array}$ & Control Group & Cognitive Tests & Main Results & $\begin{array}{l}\text { Cognitive } \\
\text { Impairment } \\
\text { Frequency }\end{array}$ \\
\hline $\begin{array}{l}\text { Afeltra et al., } \\
2003[17]\end{array}$ & $\begin{array}{l}\text { Secondary } \\
\text { APS with SLE } \\
\quad(n=61)\end{array}$ & Healthy controls & Not specified & $\begin{array}{l}\text { High titers of aPL were associated with } \\
\text { cognitive impairment } \\
\text { No details on cognitive } \\
\text { impairment patterns }\end{array}$ & $58 \%$ \\
\hline $\begin{array}{l}\text { Mikdashi et al., } \\
\text { 2004 [18] }\end{array}$ & $\begin{array}{l}\text { Secondary } \\
\text { APS with SLE } \\
(n=130)\end{array}$ & & $\begin{array}{l}\text { MMSE with other tests not } \\
\text { explicitly specified }\end{array}$ & $\begin{array}{l}\text { No details on cognitive } \\
\text { impairment patterns }\end{array}$ & $\begin{array}{l}27 \% \text { in } \\
\text { study group }\end{array}$ \\
\hline $\begin{array}{l}\text { McLaurin } \\
\text { et al., } 2005 \text { [33] }\end{array}$ & $\begin{array}{l}\text { Secondary } \\
\text { APS with SLE } \\
\quad(n=123)\end{array}$ & & $\begin{array}{l}\text { Mild impairment battery from the } \\
\text { Automated Neuropsychological } \\
\text { Assessment Metrics (ANAM). }\end{array}$ & $\begin{array}{l}\text { No details on cognitive } \\
\text { impairment patterns }\end{array}$ & $\begin{array}{l}37.5 \% \text { in } \\
\text { study group }\end{array}$ \\
\hline $\begin{array}{l}\text { Tomietto et al., } \\
2007[28]\end{array}$ & $\begin{array}{l}\text { Secondary } \\
\text { APS with SLE } \\
\quad(n=52)\end{array}$ & $\begin{array}{l}\text { Rheumatoid } \\
\text { arthritis }\end{array}$ & $\begin{array}{l}\text { Raven's progressive matrices, } \\
\text { comprehension, similarities, block } \\
\text { design, and digit symbol of Wechsler, } \\
\text { Wechsler memory scale, Rey } \\
\text { auditory-verbal learning, trail-making, } \\
\text { Corsi block, number cancellation, } \\
\text { reverse numerical sequence (MMSE), } \\
\text { Stroop word and color test, semantic and } \\
\text { phonemic verbal fluency, denomination } \\
\text { of Aachener Aphasie and token test. }\end{array}$ & $\begin{array}{l}\text { Executive functions and complex attention } \\
\text { were more frequently impaired in } \\
\text { APS patients. }\end{array}$ & $\begin{array}{l}68.6 \% \text { in study } \\
\text { group vs. } \\
41.2 \% \text { in } \\
\text { controls }\end{array}$ \\
\hline $\begin{array}{l}\text { Murray et al., } \\
2012 \text { [29] }\end{array}$ & $\begin{array}{l}\text { Secondary } \\
\text { APS with SLE } \\
\quad(n=694)\end{array}$ & & HVLT-R, COWAT & Verbal memory and verbal fluency & $\begin{array}{l}15 \% \text { in } \\
\text { entire cohort }\end{array}$ \\
\hline \multirow[t]{2}{*}{$\begin{array}{l}\text { Conti et al., } \\
2012[19]\end{array}$} & $\begin{array}{l}\text { Secondary } \\
\text { APS with SLE } \\
\quad(n=58)\end{array}$ & & $\begin{array}{l}\text { Standardized testing from ACR and the } \\
\text { CSI standardized in an } \\
\text { Italian population }\end{array}$ & Visuospatial domain mainly impaired & Missing data \\
\hline & & \multicolumn{4}{|c|}{ 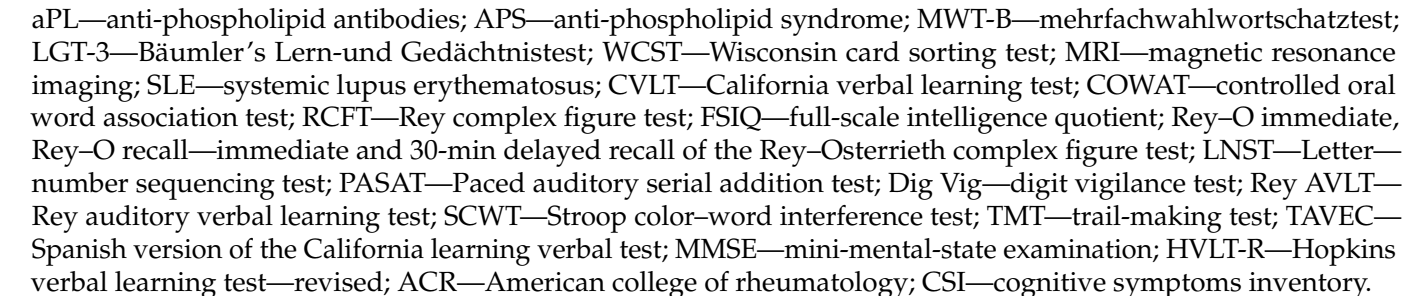 } \\
\hline
\end{tabular}

\subsection{Cognitive Impairment in aPL Carriers}

Multiple cognitive functions are impaired in aPL carriers (Table 2). The main cognitive functions affected are related to executive functioning, working memory, visual and verbal learning, verbal fluency, visuospatial ability, and visuomotor speed and flexibility (Table 2). However, gross attentional processes and fine motor skills appear to be unaffected in aPL carriers (Table 2). No association between any demographic or clinical characteristics and cognitive impairment in aPL asymptomatic carriers has been identified.

\subsection{Cognitive Impairment in APS}

A wide range of cognitive functions are impaired in primary APS (Table 2). The main cognitive functions impaired are related to visual learning, memory, visuomotor and visuospatial speed and flexibility, verbal fluency, and rapid auditory information processing [24]. Tektonidou et al. found that age and livedo reticularis were associated with cognitive impairment in primary APS, while dementia was more common with increasing age and when a greater number of abnormalities were present in electroencephalogram (EEG) and computed tomography (CT) of the brain [24].

SLE is a systemic disease affecting various tissues, including brain tissue, causing neuropsychiatric symptoms and cognitive impairment [49,50]. Kozora et al. compared cognitive function among SLE patients, aPL carriers, and healthy controls using standardized cognitive assessment tests, and brain (with functional) MRI. They showed that aPL carriers and SLE patients had abnormal brain activity, mainly affecting the frontal cortex, even when no overt clinical symptoms of cognitive decline were present [51]. This finding suggests that both conditions, aPL carrier and SLE, probably contribute to cognitive impairment. Similarly, Ilgen et al. showed that the coexistence of aPL antibodies with SLE (secondary 
APS SLE-associated) increases the risk for neurologic involvement compared to patients diagnosed with SLE without APS [52].

The main cognitive functions impaired in patients with secondary APS (mainly SLEassociated) are related to executive functions, complex attention, verbal memory and verbal fluency, as well as visuospatial domain [24]. Tektonidou et al. reported cognitive decline in both primary and secondary APS (SLE-associated) compared to healthy controls, with no differences between primary and secondary APS patients [24]. The presence of aPL antibodies, hypertension, and a history of stroke were previously described as factors associated with cognitive decline in SLE-associated secondary APS [29]. The presence of aPL antibodies was also demonstrated as an independent predictor for cognitive decline in SLE patients in other studies $[18,19]$. Gomez-Puerta et al. reported a total of 30 (25 cases from published research and 5 cases from their own cohort) patients with dementia and APS (14 had primary APS, 9 had APS secondary to SLE, and the rest had "lupus-like" disease). The authors concluded that even though dementia is not common in patients with APS, it causes significant disability [49]. A prospective study evaluated the neuropsychiatric manifestations of APS, including cognitive decline, in 1000 SLE patients with no evidence of previous strokes. In this study, as in the previous studies, the presence of aPL antibodies was found to be a predictor for the development of cognitive decline. However, this finding lost statistical significance when thromboembolic events were excluded, suggesting that, at least in this latter study, the association of cognitive decline with aPL antibodies was mostly related to thrombotic pathways rather than inflammation incited by aPL antibodies [20]. Erkan et al. analyzed the functional outcome in 39 patients with primary APS over 10 years. About $20 \%$ of these patients were functionally impaired, mainly due to cognitive dysfunction [53].

\section{Treatment}

Long-term anticoagulation with oral warfarin is a cornerstone treatment in APS patients presenting with thrombotic lesions and neurologic manifestations, including cognitive impairment [54]. Hughes reported that even features such as headache and memory loss improved with appropriate warfarin dosage [55]. The role of direct oral anticoagulant therapy for the secondary prevention of stroke in APS is still under evaluation. The ongoing Rivaroxaban in Stroke Patients with APS (RISAPS) trial aims to compare the efficacy of high-intensity rivaroxaban $15 \mathrm{mg}$ twice daily versus warfarin in the prevention of secondary stroke in APS patients [56]. Nevertheless, because of our limited understanding of the pathogenesis of cognitive impairment contributed by non-thrombotic pathways, the efficacy of immunosuppressive treatment has not been sufficiently studied [57]. Thus, no therapeutic guidelines are available for the treatment of cognitive impairment in aPL carriers and APS patients presenting with cognitive impairment without thrombotic lesions seen by brain imaging [58]. The "RITAPS" study was the first formal attempt to investigate the role of immunosuppression in the management of cognitive impairment [57]. This study was a randomized clinical trial designed to evaluate the efficacy of rituximab on non-criteria aPL manifestations, including cognitive impairment, in aPL carriers as well as APS patients. Patients received two doses of rituximab (1000 $\mathrm{mg}$ two weeks apart). The efficacy was evaluated immediately after the administration of rituximab and at 24 through 52 weeks. Cognition was evaluated using 12 tests from a standardized neuropsychological test battery endorsed by the ACR. In this study, only six patients had cognitive impairment at baseline, of whom three had a complete response, one had a partial response, and one had no response; one patient terminated the study early. The main improvements were observed in the attention, visuomotor speed, and flexibility domains. While potentially interesting, the limitations of the RITAPS study were evident and included its small sample size and relatively short follow-up period. However, the study was well designed and prospective, and it demonstrated clear benefits in the cognitive domain in association with treatment. 
The European League Against Rheumatism (EULAR)'s recommendations for the management of anti-phospholipid syndrome in adults recommend the use of low-dose aspirin for primary prevention (e.g., for the purpose of preventing the first thrombotic event) in aPL carriers with high-risk aPL profiles (defined as any of the following: multiple aPL positivity, lupus anticoagulant or persistently high aPL titers), without addressing cognitive impairment specifically [58]. Interestingly, McLaurin et al. found that consistent aspirin use was associated with improved cognitive function in older patients with SLE [33]. Hence, there is not sufficient evidence to support the use of aspirin as a primary prevention therapy for preventing cognitive impairment in aPL carriers beyond its use to prevent thrombotic events, as per this particular set of recommendations.

To date, no clinical studies have directly examined the effect of hydroxychloroquine (HCQ) on cognitive impairment in APS. HCQ is an anchor therapy in SLE, and many studies have shown favorable effects on damage accrual and survival in SLE patients [59-62]. However, these studies have not directly examined the accrual of NPSLE damage standing alone, but rather as a component of more complex composite damage scores. Groot et al. showed that HCQ was associated with an absence of damage according to the Systemic Lupus International Collaborating Clinics / American College of Rheumatology Damage Index (SDI), which includes neuropsychiatric disease [60]. Similar results were reported by Fessler et al. in the LUMINA study [61].

Ceccarelli et al., in their cohort study, evaluated changes in SLE-related cognitive impairment over 10 years. They found that cognitive impairment improved in the majority of patients, but the use of HCQ, or immunosuppressants, was not associated with a change in cognitive impairment over time [63]. Another cohort study assessed the risk of dementia in connective tissue disease patients and found no significant difference in the risk of dementia among long-term HCQ users compared to non-users [64]. Unrelated to lupus or APL, but perhaps relevant to the question of whether HCQ has neuroprotective properties, a randomized controlled trial on Alzheimer disease, which examined the effect of HCQ on progression to dementia, found no significant effect [65]. While interesting, the relevance and applicability of these studies to the question of whether HCQ is protective against cognitive dysfunction in aPL patients is limited and/or circumstantial at this point, since these studies were not designed to address this question directly.

Some case reports have demonstrated the successful treatment of aPL-associated cognitive dysfunction or neurological manifestations with mycophenolate mofetil and immunoglobulins, but properly designed prospective studies are needed to confirm their efficacy [66].

\section{Conclusions}

In summary, while cognitive impairment in APS is less studied than other manifestations of the syndrome, this type of neurologic involvement seems to be relatively common among APS patients, as well as aPL antibody carriers. The exact prevalence is unclear, mainly due to inconsistency in the tools used to identify impairment in these studies. The higher the number of the aPLs and the higher the load of the specific antibody, the greater the risk of cognitive impairment. Some evidence suggests that besides the thrombotic process, inflammatory injury plays a role in the pathogenesis of cognitive impairment in APS. The cornerstone in the treatment of APS is anti-coagulant and anti-thrombotic modalities. These treatments showed some favorable effects in reversing cognitive impairment (when there is another accepted indication for treatment), but solid evidence for the efficacy and safety of these treatments in the context of cognitive impairment is, unfortunately, still lacking.

\section{Research Agenda}

Several questions remain unanswered in the context of cognitive impairment in aPL carries and patients with APS. First, can low aspirin prevent cognitive impairment in aPL carriers? This question may be best answered by comparing patients treated with 
aspirin with untreated patients by following them prospectively for the occurrence of cognitive decline. Second, are anti-coagulant and anti-thrombotic therapies effective in the management of cognitive impairment in patients with APS? Third, is there a place for immunosuppressive therapy in treating cognitive impairment in patients with APS? Fourth, is there any effect of the cumulative duration of aPL positivity on the severity of cognition defects in APS and aPL-carriers? These are only some, but very challenging, questions that need to be addressed in the coming years.

Author Contributions: Conceptualization, M.E.N. and C.P.; methodology, F.H., M.E.N. and C.P.; software, F.H.; validation, F.H., M.E.N., C.P. and A.S.; formal analysis, F.H., M.E.N. and C.P.; investigation, F.H., M.E.N. and C.P.; resources, F.H., M.E.N. and C.P.; data curation, F.H., M.E.N. and C.P.; writingoriginal draft preparation, F.H., M.E.N. and C.P.; writing—review and editing, F.H., M.E.N., C.P. and A.S.; visualization, F.H., M.E.N. and C.P.; supervision, M.E.N. and C.P.; project administration, M.E.N. and C.P. All authors have read and agreed to the published version of the manuscript.

Funding: This research received no external funding.

Institutional Review Board Statement: Not applicable.

Informed Consent Statement: Not applicable.

Data Availability Statement: Not applicable.

Conflicts of Interest: The authors declare no conflict of interest.

\section{References}

1. Lim, W. Anti-phospholipid syndrome. Hematol. Am. Soc. Hematol. Educ. Program. 2013, 2013, 675-680. [CrossRef] [PubMed]

2. Satta, R.; Biondi, G. Anti-phospholipid syndrome and pregnancy. G. Ital. Dermatol. Venereol. 2019, 154, 277-285. [CrossRef]

3. Sanna, G.; Bertolaccini, M.L.; Cuadrado, M.J.; Khamashta, M.A. Central nervous system involvement in the anti-phospholipid (Hughes) syndrome. Rheumatology 2003, 42, 200-213. [CrossRef]

4. Yelnik, C.M.; Kozora, E.; Appenzeller, S. Non-stroke central neurologic manifestations in anti-phospholipid syndrome. Curr. Rheumatol. Rep. 2016, 18, 11. [CrossRef] [PubMed]

5. Yelnik, C.M.; Kozora, E.; Appenzeller, S. Cognitive disorders and anti-phospholipid antibodies. Autoimmun. Rev. 2016, 15, 1193-1198. [CrossRef] [PubMed]

6. Colucci, A.T.; Di Lorenzo, G.; Ingrassia, A.; Crescimanno, G. Blood anti-phospholipid antibody levels are influenced by age, sex and HLA-B8, DR3 phenotype. Exp. Clin. Immunogenet. 1992, 9, 72-79. [PubMed]

7. American Psychiatric Association. Diagnostic and Statistical Manual of Mental Disorders, 5th ed.; American Psychiatric Association: Washington, DC, USA, 2013.

8. Tsoi, K.K.; Chan, J.Y.; Hirai, H.W.; Wong, S.Y. Cognitive Tests to Detect Dementia: A Systematic Review and Meta-analysis. JAMA Intern. Med. 2015, 175, 1450-1458. [CrossRef]

9. Jacobson, M.W.; Rapport, L.J.; Keenan, P.A.; Coleman, R.D. Neuropsychological deficits associated with anti-phospholipid antibodies. J. Clin. Exp. Neuropsychol. 1999, 21, 251-264. [CrossRef]

10. Erkan, D.; Barbhaiya, M.; George, D.; Sammaritano, L. Moderate versus high-titer persistently anticardiolipin antibody positive patients: Are they clinically different and does high-titer anti-beta 2-glycoprotein-I antibody positivity offer additional predictive information? Lupus 2010, 19, 613-619. [CrossRef]

11. Kozora, E.; Erkan, D.; Zhang, L.; Zimmerman, R. Cognitive dysfunction in anti-phospholipid antibody (aPL)-negative systemic lupus erythematosus (SLE) versus aPL-positive non-SLE patients. Clin. Exp. Rheumatol. 2014, 32, $34-40$.

12. Bucci, T.; Menichelli, D.; Pignatelli, P.; Triggiani, M.; Violi, F.; Pastori, D. Relationship of Antiphospholipid Antibodies to Risk of Dementia: A Systematic Review. J. Alzheimer's Dis. 2019, 69, 561-576. [CrossRef] [PubMed]

13. Schmidt, R.; Auer-Grumbach, P.; Fazekas, F.; Offenbacher, H. Anticardiolipin antibodies in normal subjects. Neuropsychological correlates and MRI findings. Stroke 1995, 26, 749-754. [CrossRef]

14. Arvanitakis, Z.; Brey, R.L.; Rand, J.H.; Schneider, J.A. Anti-phospholipid antibodies, brain infarcts, and cognitive and motor decline in aging (ABICMA): Design of a community-based, longitudinal, clinical—Pathological study. Neuroepidemiology 2013, 40, 73-84. [CrossRef] [PubMed]

15. Mosek, A.; Yust, I.; Treves, T.A.; Vardinon, N. Dementia and anti-phospholipid antibodies. Dement. Geriatr. Cogn. Disord. 2000, 11, 36-38. [CrossRef] [PubMed]

16. Juby, A.; Davis, P.; Genge, T.; McElhaney, J. Anticardiolipin antibodies in two elderly subpopulations. Lupus 1995, 4, 482-485. [CrossRef]

17. Afeltra, A.; Garzia, P.; Mitterhofer, A.P.; Vadacca, M. Neuropsychiatric lupus syndromes: Relationship with anti-phospholipid antibodies. Neurology 2003, 8, 108-110. [CrossRef] 
18. Mikdashi, J.; Handwerger, B. Predictors of neuropsychiatric damage in systemic lupus erythematosus: Data from the Maryland Lupus Cohort. Rheumatology 2004, 43, 1555-1560. [CrossRef]

19. Conti, F.; Alessandri, C.; Perricone, C.; Scrivo, R. Neurocognitive dysfunction in systemic lupus erythematosus: Association with anti-phospholipid antibodies, disease activity and chronic damage. PLoS ONE 2012, 7, e33824.

20. Borowoy, A.M.; Pope, J.E.; Silverman, E.; Fortin, P.R. Neuropsychiatric lupus: The prevalence and autoantibody associations depend on the definition: Results from the 1000 faces of lupus cohort. Semin. Arthritis Rheum. 2012, 42, 179-185. [CrossRef]

21. Hanly, J.G.; Hong, C.; Smith, S.; Fisk, J.D. A prospective analysis of cognitive function and anticardiolipin antibodies in systemic lupus erythematosus. Arthritis Rheum. 1999, 42, 728-734. [CrossRef]

22. Riancho-Zarrabeitia, L.; Martínez-Taboada, V.M.; Rúa-Figueroa, I.; Alonso, F. Do all anti-phospholipid antibodies confer the same risk for major organ involvement in systemic lupus erythematosus patients? Clin. Exp. Rheumatol. 2021, 39, 555-563. [PubMed]

23. Coín, M.A.; Vilar-López, R.; Peralta-Ramírez, I.; Hidalgo-Ruzzante, N. The role of anti-phospholipid autoantibodies in the cognitive deficits of patients with systemic lupus erythematosus. Lupus 2015, 24, 875-879. [CrossRef] [PubMed]

24. Tektonidou, M.G.; Varsou, N.; Kotoulas, G.; Antoniou, A. Cognitive deficits in patients with anti-phospholipid syndrome: Association with clinical, laboratory, and brain magnetic resonance imaging findings. Arch. Intern. Med. 2006, 13, $2278-2284$. [CrossRef] [PubMed]

25. Maeshima, E.; Yamada, Y.; Yukawa, S.; Nomoto, H. Higher cortical dysfunction, anti-phospholipid antibodies and neuroradiological examinations in systemic lupus erythematosus. Intern. Med. 1992, 31, 1169-1174. [CrossRef]

26. Denburg, S.D.; Carbotte, R.M.; Ginsberg, J.S.; Denburg, J.A. The relationship of anti-phospholipid antibodies to cognitive function in patients with systemic lupus erythematosus. J. Int. Neuropsychol. Soc. 1997, 3, 377-386. [CrossRef] [PubMed]

27. Sanna, G.; Bertolaccini, M.L.; Cuadrado, M.J.; Laing, H. Neuropsychiatric manifestations in systemic lupus erythematosus: Prevalence and association with anti-phospholipid antibodies. J. Rheumatol. 2003, 30, 985-992.

28. Tomietto, P.; Annese, V.; D'agostini, S.; Venturini, P. General and specific factors associated with severity of cognitive impairment in systemic lupus erythematosus. Arthritis Rheum. 2007, 15, 1461-1472. [CrossRef]

29. Murray, S.G.; Yazdany, J.; Kaiser, R.; Criswell, L.A. Cardiovascular disease and cognitive dysfunction in systemic lupus erythematosus. Arthritis Care Res. 2012, 64, 1328-1333. [CrossRef]

30. Cervera, R.; Piette, J.-C.; Font, J.; Khamashta, M.A. Anti-phospholipid syndrome: Clinical and immunologic manifestations and patterns of disease expression in a cohort of 1000 patients. Arthritis Rheum. 2002, 46, 1019-1027. [CrossRef]

31. Etemadifar, M.; Dehghani, L.; Tahani, S.; Toghianifar, N. Neurological manifestations in patients with anti-phospholipid syndrome. Iran J. Neurol. 2013, 12, 172-175.

32. Chapman, J.; Abu-Katash, M.; Inzelberg, R.; Yust, I. Prevalence and clinical features of dementia associated with the antiphospholipid syndrome and circulating anticoagulants. J. Neurol. Sci. 2002, 15, 81-84. [CrossRef]

33. McLaurin, E.Y.; Holliday, S.L.; Williams, P.; Brey, R.L. Predictors of cognitive dysfunction in patients with systemic lupus erythematosus. Neurology 2005, 25, 297-303. [CrossRef] [PubMed]

34. Menon, S.; Jameson-Shortall, E.; Newman, S.P.; Hall-Craggs, M.R. A longitudinal study of anticardiolipin antibody levels and cognitive functioning in systemic lupus erythematosus. Arthritis Rheum. 1999, 42, 735-741. [CrossRef]

35. Hanly, J.G.; McCurdy, G.; Fougere, L.; Douglas, J.-A. Neuropsychiatric events in systemic lupus erythematosus: Attribution and clinical significance. J. Rheumatol. 2004, 31, 2156-2162. [PubMed]

36. Donnellan, C.; Cohen, H.; Werring, D.J. Cognitive dysfunction and associated neuroimaging biomarkers in antiphospholipid syndrome: A systematic review. Rheumatology 2021, 61, 24-41. [CrossRef]

37. Man, Y.L.; Sanna, G. Neuropsychiatric Manifestations of Antiphospholipid Syndrome-A Narrative Review. Brain Sci. 2022, 12, 91. [CrossRef]

38. Sevim, E.; Zisa, D.; Andrade, D.; Sciascia, S.; Pengo, V.; Tektonidou, M.G.; Ugarte, A.; Gerosa, M.; Belmont, H.M.; Zamorano, M.A.A.; et al. Characteristics of Patients with Antiphospholipid Antibody Positivity in the APS ACTION International Clinical Database and Repository. Arthritis Care Res. 2020, 74, 324-335. [CrossRef]

39. Antovic, A.; Bruzelius, M. Impaired Fibrinolysis in the Antiphospholipid Syndrome. Semin. Thromb. Hemost. 2021, 47, 506-511. [CrossRef]

40. Katzav, A.; Pick, C.G.; Korczyn, A.D.; Oest, E. Hyperactivity in a mouse model of the anti-phospholipid syndrome. Lupus 2001, 10, 496-499. [CrossRef]

41. Ziporen, L.; Shoenfeld, Y.; Levy, Y.; Korczyn, A.D. Neurological dysfunction and hyperactive behavior associated with antiphospholipid antibodies. A mouse model. J. Clin. Investig. 1997, 1, 613-619. [CrossRef]

42. Katzav, A.; Ben-Ziv, T.; Blank, M.; Pick, C.G. Antibody-specific behavioral effects: Intracerebroventricular injection of antiphospholipid antibodies induces hyperactive behavior while anti-ribosomal-P antibodies induces depression and smell deficits in mice. J. Neuroimmunol. 2014, 15, 10-15. [CrossRef] [PubMed]

43. Appenzeller, S.; Lapa, A.T.; de Carvalho, J.F.; Peres, F.A. Cognitive dysfunction and anti-phospholipid antibodies. Curr. Rheumatol. Rep. 2012, 14, 95-98. [CrossRef] [PubMed]

44. Shoenfeld, Y.; Nahum, A.; Korczyn, A.D.; Dano, M. Neuronal-binding antibodies from patients with anti-phospholipid syndrome induce cognitive deficits following intrathecal passive transfer. Lupus 2003, 12, 436-442. [CrossRef] [PubMed] 
45. Frauenknecht, K.; Katzav, A.; Lavi, R.W.; Sabag, A. Mice with experimental anti-phospholipid syndrome display hippocampal dysfunction and a reduction of dendritic complexity in hippocampal CA1 neurones. Neuropathol. Appl. Neurobiol. 2015, 41, 657-671. [CrossRef] [PubMed]

46. Van Horn, G.; Arnett, F.C.; Dimachkie, M.M. Reversible dementia and chorea in a young woman with the lupus anticoagulant. Neurology 1996, 46, 1599-1603. [CrossRef]

47. Rosa, R.F.; Ugolini-Lopes, M.R.; Gandara, A.P.R.; Vendramini, M.B.G.; Campanholo, K.R.; Dutra, L.; de Andrade, D.C.O. Cognitive dysfunction and serum levels of brain-derived neurotrophic factor (BDNF) in primary anti-phospholipid syndrome (PAPS) Rheumatology 2021, 60, 179-187. [CrossRef]

48. Howieson, D. Current limitations of neuropsychological tests and assessment procedures. Clin. Neuropsychol. 2019, 33, 200-208. [CrossRef]

49. Gómez-Puerta, J.A.; Cervera, R.; Calvo, L.M.; Gómez-Ansón, B.; Espinosa, G.; Claver, G.; Bucciarelli, S.; Bové, A.; Ramos-Casals, M.; Ingelmo, M.; et al. Dementia associated with the antiphospholipid syndrome: Clinical and radiological characteristics of 30 patients. Rheumatology 2005, 44, 95-99. [CrossRef]

50. Zhao, Z.; Rocha, N.P.; Salem, H.; Diniz, B.S. The association between systemic lupus erythematosus and dementia A meta-analysis. Dement. Neuropsychol. 2018, 12, 143-151. [CrossRef]

51. Kozora, E.; Uluğ, A.M.; Erkan, D.; Vo, A.; Filley, C.M. Functional Magnetic Resonance Imaging of Working Memory and Executive Dysfunction in Systemic Lupus Erythematosus and Antiphospholipid Antibody-Positive Patients. Arthritis Care Res. 2016, 68, 1655-1663. [CrossRef]

52. İlgen, U.; Yayla, M.E.; Ateş, A.; Okatan, İ.E. Antiphospholipid antibodies and non-thrombotic manifestations of systemic lupus erythematosus. Lupus 2018, 27, 665-669. [CrossRef] [PubMed]

53. Erkan, D.; Yazici, Y.; Sobel, R.; Lockshin, M.D. Primary anti-phospholipid syndrome: Functional outcome after 10 years. J. Rheumatol. 2000, 27, 2817-2821. [PubMed]

54. Ruiz-Irastorza, G.; Cuadrado, M.; Ruiz-Arruza, I.; Brey, R. Evidence-based recommendations for the prevention and long-term management of thrombosis in anti-phospholipid antibody-positive patients: Report of a Task Force at the13th International Congress on Anti-phospholipid Antibodies. Lupus 2011, 20, 206-218. [CrossRef]

55. Hughes, G.R. Migraine, memory loss, and multiple sclerosis. Neurological features of the anti-phospholipid (Hughes') syndrome. Postgrad. Med. J. 2003, 79, 81-83. [CrossRef] [PubMed]

56. ClinicalTrials.gov. RIvaroxaban for Stroke Patients with AntiPhospholipid Syndrome (RISAPS). Identifier: NCT03684564 Available online: https:/ / clinicaltrials.gov / ct2/show/NCT03684564 (accessed on 30 October 2021).

57. Erkan, D.; Vega, J.; Ramón, G.; Kozora, E. A pilot open-label phase II trial of rituximab for non-criteria manifestations of anti-phospholipid syndrome. Arthritis Rheum. 2013, 65, 464-471. [CrossRef] [PubMed]

58. Tektonidou, M.G.; Andreoli, L.; Limper, M.; Amoura, Z. EULAR recommendations for the management of anti-phospholipid syndrome in adults. Ann. Rheum. Dis. 2019, 78, 1296-1304. [CrossRef] [PubMed]

59. Jin, Z.; Wang, F.; Pan, W.; Liu, L.; Wu, M.; Hu, H.; Ding, X.; Wei, H.; Zou, Y.; Qian, X.; et al. Association of antimalarial drugs with decreased overall and cause specific mortality in systemic lupus erythematosus. Rheumatology 2021, 60, 1774-1783. [CrossRef]

60. Groot, N.; Shaikhani, D.; Teng, Y.K.O.; de Leeuw, K.; Bijl, M.; Dolhain, R.J.E.M.; Zirkzee, E.; Fritsch-Stork, R.; Bultink, I.E.M.; Kamphuis, S. Long-Term Clinical Outcomes in a Cohort of Adults with Childhood-Onset Systemic Lupus Erythematosus. Arthritis Rheumatol. 2019, 71, 290-301. [CrossRef]

61. Fessler, B.J.; Alarcón, G.S.; McGwin, G.; Roseman, J.; Bastian, H.M.; Friedman, A.W.; Baethge, B.A.; Vilá, L.; Reveille, J.D. LUMINA Study Group. Systemic lupus erythematosus in three ethnic groups: XVI. Association of hydroxychloroquine use with reduced risk of damage accrual. Arthritis Rheum. 2005, 52, 1473-1480. [CrossRef]

62. Mimica, M.; Barra, I.; Ormeño, R.; Flores, P.; Calderón, J.; Padilla, O.; Bravo-Zehnder, M.; González, A.; Massardo, L. Predictors of damage accrual in systemic lupus erythematosus: A longitudinal observational study with focus on neuropsychological factors and anti-neuronal antibodies. Clin. Rheumatol. 2019, 38, 3129-3137. [CrossRef]

63. Ceccarelli, F.; Perricone, C.; Pirone, C.; Massaro, L.; Alessandri, C.; Mina, C.; Marianetti, M.; Spinelli, F.R.; Valesini, G.; Conti, F. Cognitive dysfunction improves in systemic lupus erythematosus: Results of a 10 years prospective study. PLoS ONE 2018, 13, e0196103. [CrossRef] [PubMed]

64. Crocker, T.F.; Brown, L.; Lam, N.; Wray, F.; Knapp, P.; Forster, A. Information provision for stroke survivors and their carers Cochrane Database Syst. Rev. 2021, 2021. [CrossRef]

65. Fardet, L.; Nazareth, I.; Petersen, I. Chronic hydroxychloroquine/chloroquine exposure for connective tissue diseases and risk of Alzheimer's disease: A population-based cohort study. Ann. Rheum. Dis. 2019, 78, 279-282. [CrossRef] [PubMed]

66. Xourgia, E.; Tektonidou, M.G. Management of Non-criteria Manifestations in Antiphospholipid Syndrome. Curr. Rheumatol. Rep. 2020, 22, 51. [CrossRef] 